Despite greater knowledge and possibilities in pharmacotherapy, fungal infections remain a challenge for clinicians. As the population of immunocompromised patients and those treated for their hematologic ailments increases, the number of fungal infections grows too. This is why there is still a quest for new antifungal drugs as well as for optimization of pharmacotherapy with already registered pharmaceutics.

Voriconazole and posaconazole are broad-spectrum, new generation, triazole antifungal agents. The drugs are used in the pharmacotherapy of invasive aspergillosis, Candida and Fusarium infections. Voriconazole is also used in infections caused by Scedosporium. Posaconazole is used in the treatment of coccidioidomycosis and chromoblastomycosis. Besides some similarities, the two mentioned drugs also show differences in therapeutic indications, pharmacokinetics (mainly absorption and metabolism), frequency and severity of adverse drug reactions, drug-drug interactions and dosage. As both of the drugs are used in the treatment of invasive fungal infections in adults and children, detailed knowledge of the clinical pharmacology of antifungal agents is the main factor in pharmacotherapy optimization in treatment of fungal infections.

The goal of the article is to present and compare the clinical pharmacology of voriconazole and posaconazole as well as to point out the indications and contraindications of using the drugs, determine factors influencing their pharmacotherapy, and provide information that might be helpful in the treatment of fungal infections.

Key words: voriconazole, posaconazole, clinical pharmacology, cytochrome P-450 enzyme system, drug monitoring.

Contemp Oncol (Pozn) 2016; 20 (5): 365-373 DOI: $10.5114 /$ wo.2016.64594

\section{Comparison of clinical pharmacology of voriconazole and posaconazole}

\author{
Beata M. Sienkiewicz, Łukasz Łapiński, Anna Wiela-Hojeńska
}

Wroclaw Medical University, Wroclaw, Poland

\section{Introduction}

Fungal infections are one of the most severe problems in clinical practice, especially in hematology and oncology units. They make up from 9 to 10\% of all infections developing among hospitalized patients. Fungemia can be either a complication connected with the malignancy itself or an adverse effect of the oncological treatment (chemo-, radio- and corticotherapy). Furthermore, it can influence the final result of treatment. In the group of patients with oncological diseases, allogenic bone marrow transplantations, relapse of leukemia, pancytopenia lasting longer than ten days, undergoing corticotherapy and broad-spectrum antibiotic therapy, immunosuppressive treatment and graft versus host disease (GVHD) are the main factors predisposing to fungal infections. Pathogens mainly responsible for invasive fungal infections (IFI) are Candida spp. and Aspergillus spp. The first kind often develops as a concurrent illness during acute mucosa inflammation, infections connected with central venous catheters and the use of broad-spectrum antibiotics, and pre-existing colonization with the pathogen in at least one body area. The second kind leads to infection resulting from inhalation of spores from the air. This is why pulmonary aspergillosis is one of the most frequent infections caused by Aspergillus spp. (87\% of patients), followed by sinusitis and rhinitis (16\%), and less frequently encephalitis (8\%). The risk factors of aspergillosis are neutropenia lasting for longer than two weeks, staying in an endemic region, tuberculosis and cytomegalic virus infection. The risk factors promoting fungal infections are presented in Table 1 [1-8].

The frequency of fungal infections is still growing, and the prophylactic and empiric antifungal treatment using extended spectrum drugs leads to development of resistance. Unfortunately, such infections are not easy to diagnose, especially in their early stages. This is mainly connected with their nonspecific nature - similar to virus and bacterial infections, affecting immunocompromised patients, few symptoms usually limited to pyrexia, decreased options of diagnostic testing in patients in a serious condition, and false negative results of performed diagnostic tests. It has been determined that the median mortality rate among patients, after chemotherapy, caused by invasive yeast infections is 39\% and it varies among different types of fungi. As an example, the mortality rate in Aspergillus spp. infections is $49.3 \%$ and it can rise to $86.7 \%$ in patients after hematopoietic cell transplantation. For patients with candidiasis the mortality rate is about 14-36\%, for invasive fusariosis it is much higher, and varies from 66 to $75 \%$, and for scedosporiosis the estimated mortality rate is between 65 and 100\% [9-11]. Every patient with neutropenia and long lasting pyrexia who is not getting better after antibiotic therapy should be suspected of fungal infection, and there is an urgent need to perform laboratory tests. Diagnostic procedures covering microscopic, microbiologic, serologic and genetic testing help to decide which pharmacological treatment would be the best [2, 3, 12].

For over 40 years, the treatment of fungal infections was based on amphotericin B. The numerous adverse effects, especially nephrotoxicity, forced sci- 
Table 1. Risk factors promoting fungal infections

\begin{tabular}{|c|c|c|c|}
\hline \multicolumn{4}{|c|}{ Factors connected with: } \\
\hline the patient & ailments & $\begin{array}{l}\text { hospitalization and } \\
\text { medical invasive procedures }\end{array}$ & chemo-, radio- and corticotherapy \\
\hline $\begin{array}{l}\text { Born SGA (small for } \\
\text { gestational age) }\end{array}$ & $\begin{array}{l}\text { Disorders of the humoral and } \\
\text { cell-mediated immunity }\end{array}$ & $\begin{array}{l}\text { Long-term use of central venous } \\
\text { catheters }\end{array}$ & $\begin{array}{l}\text { Damage of skin and mucous membrane } \\
\text { integrity due to chemo- and radiotherapy }\end{array}$ \\
\hline $\begin{array}{l}\text { Colonization with } \\
\text { Candida fungus }\end{array}$ & $\begin{array}{l}\text { Deterioration of phagocytosis and } \\
\text { intracellular bacterial lysis }\end{array}$ & Central lines & $\begin{array}{l}\text { Long-term use of immunosuppressive } \\
\text { drugs }\end{array}$ \\
\hline $\begin{array}{l}\text { Damage of natural } \\
\text { barriers }\end{array}$ & $\begin{array}{l}\text { Disorders in function of } \mathrm{B} \text { and } \mathrm{T} \\
\text { lymphocytes }\end{array}$ & $\begin{array}{l}\text { Abdominal cavity surgery } \\
\text { (especially repeatedly performed, } \\
\text { and complicated) }\end{array}$ & Long-term use of monoclonal antibodies \\
\hline \multirow[t]{8}{*}{$\begin{array}{l}\text { Protein and energetic } \\
\text { insufficiency }\end{array}$} & $\begin{array}{l}\text { Reduction of immunoglobulin } \\
\text { production }\end{array}$ & $\begin{array}{l}\text { Organ transplantation (especially } \\
\text { liver transplantation) }\end{array}$ & Long-term cortico- and antibiotic therapy \\
\hline & Complement system disorders & Dialysis & \\
\hline & $\begin{array}{l}\text { Long-term neutropenia (> } 9 \text { days) } \\
\text { lymphopenia, monocytopenia }\end{array}$ & Parenteral nutrition & \\
\hline & Alkalization of body fluids & $\begin{array}{l}\text { Colonization of skin and mucosa } \\
\text { with hospital bacterial flora }\end{array}$ & \\
\hline & $\begin{array}{l}\text { Gastrointestinal tract passage } \\
\text { disorders }\end{array}$ & Long-term hospitalization & \\
\hline & Bacterial infections & & \\
\hline & Necrotizing pancreatitis & & \\
\hline & Running malignant disease & & \\
\hline
\end{tabular}

entists to search for other drugs. In the 1980s, a new generation - azole antifungal drugs - entered therapeutic use. Depending on the amount of nitrogen atoms in the azole ring, the new pharmacotherapeutic group has been divided into imidazoles (with 2 nitrogen atoms) represented by ketoconazole, miconazole, clotrimazole, tioconazole, econazole, isoconazole, and triazoles ( 3 nitrogen atoms) - the first generation with fluconazole and itraconazole, the second generation with voriconazole and posaconazole $[13,14]$.

The goal of this article is to present and compare the clinical pharmacology of the new generation triazole drugs voriconazole (approved for therapy in 2002) and posaconazole (approved for therapy in 2006) [13].

\section{Mode of action and therapeutic indications}

The mode of action of voriconazole and posaconazole is the inhibition of fungal cytochrome P450 mediated 14-alpha lanosterol demethylation, which causes damage in the structure and the loss of cell membrane function. Voriconazole is a broad spectrum antifungal agent indicated for the treatment of candidiasis also caused by fluconazole-resistant $C$. glabrata and $C$. krusei. Moreover, it can be used in Aspergillus (A. flavus, A. fumigatus, A. terreus, A. niger, A. nidulans), Cryptococcus neoformans, Fusarium, Scedosporium, Penicillium, Alternaria, Blastomyces dermatidis, Blastoschizomyces capitatus, Cladosporium, Coccidioides immitis, Conidiobolus coronatus, Madurella mycetomatis, Exserohilum rostratum, Exophiala spinifera, Fonsecaea pedrosoi, Paecilomyces lilacinus, Phialophora richardsiae, Scopulariopsis brevicaulis, and Trichosporon infections. It has a greater activity against most molds compared with amphotericin B [13-19].
The main indications for treatment with voriconazole are invasive aspergillosis (first line treatment [15, 20]), candidiasis in non-neutropenic patients, fluconazole-resistant severe invasive Candida infections (including C. krusei) and also invasive Scedosporium spp. and Fusarium spp. infections (first line treatment [20]). The drug can be used in children older than two years, and in adults. It is classified as $C$ in the FDA Pregnancy Categorization, which means that the drug can be used in pregnant women only when the benefits for the mother outweigh the risk for the fetus. It is contraindicated during lactation [16].

In the prevention of fungal infections, no greater effectiveness of voriconazole over fluconazole has been established. A decrease in the mortality rate compared with amphotericin B treatment in the group of patients with invasive aspergillosis has been observed [18]. Voriconazole is available on the market in the form of film-coated tablets, oral suspension, and as an infusion [20]. It should be administered a minimum of $1 \mathrm{~h}$ before meals. A contraindication for the use of voriconazole is hypersensitivity to the drug itself or other azoles. During the treatment, liver and kidney biochemical parameters should be monitored. The patients should avoid long exposure to the sun. Photosensitivity usually develops after 12 weeks of treatment [15].

According to numerous adverse drug reactions (ADR), the duration of antifungal therapy should be as short as possible. In cases of treatment longer than 6 months, the risk-benefit balance should be considered [16].

Posaconazole is also a broad spectrum antifungal agent indicated in first line prophylaxis of invasive Aspergillus spp. and Candida spp. infections. However, its range of action is very similar to voriconazole, and so posacon- 
Table 2. Main therapeutic indications for voriconazole and posaconazole

\begin{tabular}{lcc} 
Indication & Voriconazole & Posaconazole \\
\hline Invasive aspergillosis & + (treatment) & + (prophylaxis and treatment) \\
Candidiasis & + (treatment) & + (prophylaxis and treatment) \\
Fusariosis & + (treatment) & + (prophylaxis and treatment) \\
$\begin{array}{l}\text { Scedosporium spp. infections } \\
\text { Coccidioidomycosis }\end{array}$ & + (treatment) & - \\
Chromoblastomycosis & - & + (prophylaxis and treatment) \\
Invasive fungal infections in high-risk HSCT (hematopoietic stem cell & + (prophylaxis) & + (prophylaxis and treatment) \\
transplant) recipients including: patients with AML, and patients who & & + (prophylaxis) \\
have received myeloablative conditioning regimens & &
\end{tabular}

azole can also be used in the treatment of Zygomycetes, Coccidioides and Chromoblastomyces infections. Cases of effective treatment of the central nervous system, pulmonary system and the treatment in cases of Ramichloridium mackenziei, Fusarium proliferatum, and Rhizopus infections have been published [21-23]. The drug is available on the market in the form of film-coated tablets, oral suspension, and as an infusion. The intravenous formulation is available in the USA, the European Union and Canada, where it has been approved by the proper medicine agencies. In contrast to the previously described voriconazole, the molecule of posaconazole has a lipophilic character which leads to differences in administration of both drugs. It was the first medicine used in patients undergoing intensive chemotherapy to induce remission. The drug was developed for prophylaxis and treatment in patients with immunodeficiency, hematological ailments and persons after bone marrow transplantation treated with high doses of immunosuppressive drugs to prevent GVHD [15, 20, 24].

Posaconazole is used in primary treatment of oral candidiasis in patients with immunodeficiency where a limited response to local treatment is expected. Other indications are pharmacotherapy and prophylaxis of invasive aspergillosis refractory to amphotericin B and itraconazole and in the case of intolerance to the first line treatment, also with voriconazole. As the second line treatment, posaconazole is used in fusariosis (in the case of intolerance to amphotericin B), chromoblastomycosis (in the case of intolerance to itraconazole), coccidioidomycosis (in the case of intolerance or refractory to amphotericin B, itraconazole and fluconazole) [24].

Unfortunately, molds resistant to posaconazole and voriconazole have already been isolated, mainly in the Candida spp. and Aspergillus spp. strains [24-26]. The main mechanism of resistance is the change of functional groups in the target protein CYP51 [15, 17, 24]. This resistance can constitute a clinically relevant problem. It has to be remembered that this is not the only mechanism of resistance to azoles, and that in fungi, always several mechanisms are involved at the same time. Apart from the lack or weakness of drug penetration resulting from changes in the composition of sterols and phospholipids in the fungal cell, changes in the efflux process of the drug, defects in the drug metabolizing cytochrome P450 enzymes and changes of the drug itself play a great role in the development of resistance.
In contrast to the bacterial one, the resistance to azoles in fungi may or may not affect cross-resistance to other drugs from the same group [27].

The main treatment indications for voriconazole and posaconazole are shown in Table 2 [16, 24].

\section{Pharmacokinetic properties and dosage regimen}

The pharmacokinetics of voriconazole are non-linear in adults. The absorption is rapid and almost complete after oral administration. The maximum plasma concentration is achieved after 1-2 hours. The bioavailability is about $96 \%$. The best absorption is achieved when voriconazole is administered twice daily in the first $24 \mathrm{~h}$ via the loading dose and after the first day via the maintenance dose [16, 20, 28, 29]. Lower voriconazole concentrations have been reported after oral administration, which is why careful drug monitoring needs to be performed in cases of switch from an intravenous (i.v.) to an oral formulation [30].

The distribution volume is $4.6 \mathrm{l} / \mathrm{kg}$, which proves a good penetration of the drug into tissues. Plasma protein binding is estimated to be $58 \%$. The drug penetrates to the cerebral fluid [16].

Voriconazole is metabolized in the liver via the CYP2C9, CYP3A4 and CYP2C19 isoenzymes, forming non-active metabolites. The genetic polymorphism of CYP2C19 isoenzyme has a great influence on inter-individual variability of pharmacokinetic parameters [16, 31]. Table 3 presents the main information about the mentioned isoenzyme, its alleles, the influence of genotype on the metabolism of voriconazole and measured serum levels. The influence of CYP2C19*9-*16 is not known yet [32].

The median half-life of voriconazole is approximately $6 \mathrm{~h}$ depending on the dose. Multiple dosing or i.v. administration increases the parameter [16].

Voriconazole is metabolized mainly in the liver; only $2 \%$ of the administered dose is excreted in an unchanged form in the urine.

There is no need of dose regimen modification according to gender. Dolton et al. suggest that there is no relation between body weight and dose requirements. However, some cases of side effects in obese patients treated with doses determined according to actual weight have been reported, whereas there have been no adverse drug reactions (ADR) if voriconazole was administered in weight-independent dosage regimens $[30,33,34]$. The dose should 
Table 3. CYP2C19 isoenzyme and the influence of its mutations on the metabolism of voriconazole and the drug serum levels

\begin{tabular}{|c|c|c|c|c|c|c|c|}
\hline \multirow[t]{2}{*}{ Allele } & \multirow{2}{*}{$\begin{array}{l}\text { Enzymatic } \\
\text { activity }\end{array}$} & \multicolumn{3}{|c|}{ Percentage in population } & \multirow{2}{*}{$\begin{array}{l}\text { CYP2C19 } \\
\text { genotype }\end{array}$} & \multirow{2}{*}{$\begin{array}{c}\text { Type of } \\
\text { metabolism }\end{array}$} & \multirow{2}{*}{$\begin{array}{l}\text { Changes of serum levels after } \\
\text { standard dose application }\end{array}$} \\
\hline & & Caucasian & Afro-American & Asiatic & & & \\
\hline \multirow[t]{2}{*}{${ }^{\star} 2$} & loss & 12 & 15 & 29-35 & $* 2 / * 2$ & PM & $\uparrow$ \\
\hline & & & & & ${ }^{*} 1 /{ }^{*} 2$ & IM & \\
\hline \multirow[t]{3}{*}{ *3 } & $\downarrow$ & $<1$ & $<1$ & $2-9$ & ${ }^{*} 1 /{ }^{*} 3$ & $\mathrm{IM}$ & \\
\hline & & & & & $* 2 / * 3$ & PM & $\uparrow$ \\
\hline & & & & & *3/*3 & $P M$ & \\
\hline *4 & $\downarrow$ & $<1$ & $<1$ & $<1$ & * $1 /{ }^{\star} 4$ & $\mathrm{IM}$ & $\uparrow$ \\
\hline *5 & $\downarrow$ & $<1$ & $<1$ & $<1$ & ${ }^{\star} 1 /{ }^{\star} 5$ & $\mathrm{IM}$ & $\uparrow$ \\
\hline *6 & $\downarrow$ & $<1$ & $<1$ & $<1$ & ${ }^{*} 1 /{ }^{*} 6$ & IM & $\uparrow$ \\
\hline *7 & $\downarrow$ & $<1$ & $<1$ & $<1$ & ${ }^{\star} 1 /{ }^{*} 7$ & IM & $\uparrow$ \\
\hline *8 & $\downarrow$ & $<1$ & $<1$ & $<1$ & ${ }^{\star} 1 /{ }^{*} 8$ & $\mathrm{IM}$ & $\uparrow$ \\
\hline \multirow[t]{2}{*}{ *17 } & $\uparrow$ & 21 & 16 & 3 & ${ }^{\star} 1 /{ }^{\star} 17$ & EM & $\downarrow$ \\
\hline & & & & & ${ }^{*} 17 /{ }^{*} 17$ & UM & \\
\hline
\end{tabular}

PM - poor metabolism; IM - intermediate metabolism; EM - extensive metabolism; UM - ultra rapid metabolism

be elevated in children because of the more frequent inter-individual variability in the pediatric population. The i.v. way of administration is preferred in children with low body mass and absorption disturbances [16, 20].

For the adult population, no effective method of PK/PD modeling has been established, which may be associated with a limited number of data on the pharmacokinetics of voriconazole in the group of patients suffering from invasive fungal infections [35]. In adults, a loading dose of 400 mg every $12 \mathrm{~h}$ and a maintenance dose of $200 \mathrm{mg}$ every $12 \mathrm{~h}$ is recommended [16]. For comparison, two pharmacokinetic models have been established for the pediatric population [35]. In the independent studies performed by Karlsson et al. and Neely et al. a loading dose of $7 \mathrm{mg} / \mathrm{kg}$ body mass for i.v. and $200 \mathrm{mg}$ every $12 \mathrm{~h}$ for the oral formulation has been established $[36,37]$. Kuo et al. stated that the best model describing the pharmacokinetics of voriconazole in the pediatric population is a linear model [38].

Posaconazole pharmacokinetics are linear, best described by a one-compartment pharmacokinetic model with first order elimination [39]. After the oral administration, the absorption of the drug depends on the dose regimen and the amount of fat in the food. The bioavailability is higher when the drug is administered in four divided doses. Co-administration with PPI (proton pump inhibitors) and metoclopramide and also inflammatory states such as mucositis reduce the bioavailability of oral posaconazole formulations [39]. After the administration of $800 \mathrm{mg}$ of posaconazole in two doses, every 12 hours, the parameter is 98\%; after dividing the dose into four smaller doses every $6 \mathrm{~h}$ it rises to $220 \%$. The saturation of absorption has been observed after using doses above 800 mg. After a single dose administration, the time needed to reach maximal concentration $\left(C_{\max }\right)$ is about 5-8 hours. The plasma protein binding level is $98 \%$. The lipophilic posaconazole is characterized by a distribution rate of about $5-25 \mathrm{l} / \mathrm{kg}$ which suggests distribution in the extravascular space and penetration into the intracellular space $[24,40$,
41]. Intravenous posaconazole formulations are well tolerated when administered in a single dose of $300 \mathrm{mg}$ during 30 minutes. However, careful infusion site monitoring is recommended. The multiple dosing of posaconazole i.v. formulations leads to high rates of infusion side effects, such as thrombophlebitis [42].

Posaconazole is metabolized through the $2^{\text {nd }}$ phase biotransformation, mainly by UDP-glucuronyltransferase. Only $2 \%$ of the administered dose is oxidized via the P450 cytochrome isoenzymes. The drug is a substrate and an inhibitor of P-glycoprotein. The metabolites formed by the P450 enzymes make up only a small amount of circulating metabolites [40, 41].

Posaconazole is predominantly eliminated with feces in an unchanged form (77\%). Only about $14 \%$ is excreted with urine. The half-life is about $35 \mathrm{~h}$, and the steady state is achieved after 5-7 days of administration [20, 24, 41].

Studies carried out in the pediatric population from 8 to 17 years of age showed a similar safety profile to the one observed in adults. Nonetheless, the number of patients was small, so there is a need for more similar studies to prove the hypothesis. In elderly patients, an increase of the $C_{\max }$ and AUC (area under the curve) of about 29\% was observed, what may suggest the need of dose regimen modification in this group of patients [24].

\section{Factors influencing the pharmacokinetics}

Food intake affects the bioavailability of voriconazole and decreases it by about $22 \%$. This is considered to be an indication for administration of the drug on an empty stomach [16]. The gastric pH does not influence the solubility or absorption of the drug [43]. A second factor influencing the voriconazole pharmacokinetics is the patients' genotype. Especially the CYP2C19 mutation previously described plays a great role. Hepatic impairment also influences the pharmacokinetics. Studies have shown 2.5-fold higher AUC values in patients with hepatic disturbances (Child-Pugh classification A and B), which suggests 
the need of drug regimen modification in this group of patients. An influential problem is the absence of clinical data from patients with fatal hepatic impairment. Among patients with renal failure, there is no need of drug regimen modification, but cyclodextrin, an intra-venous formulation excipient, can cumulate in the organism. The influence of this phenomenon has not been explained yet - hence caution in the use of i.v. formulations in patients with renal impairment is recommended [16, 38].

Posaconazole is better absorbed when it is administered with high fat meals in four doses of $200 \mathrm{mg}$. Its pharmacokinetics are influenced by coexistent ailments affecting the gastrointestinal motility (diarrhea, mucosa inflammation) and GVHD. Studies on healthy volunteers did not show that gender and ethnicity affect the pharmacokinetics [24, 40, 41]. It has been demonstrated that in elderly patients, the serum concentration of posaconazole is higher due to a lower apparent volume of distribution [44]. There is no need for drug regimen modification in patients with renal impairment. However, hepatic disturbances (2-fold higher $\gamma$-glutamyl transpeptidase [GGT]) and drug administration through a nasogastric tube can be an indication for dose regimen modification [14, 44].

\section{Adverse drug reactions}

Voriconazole is a well-tolerated drug. The most frequently occurring ADR are visual disturbances (23-35\%) demonstrated as color vision change, blurred vision, scotoma and photophobia. These reactions appear at the time of administration and return to normal after about 30 minutes. Moreover, skin reactions such as rash (usually mild severity), gastric disturbances, hepatic disturbances (elevation of AST, ALT, alkaline phosphatase, GGT, lactate dehydrogenase, bilirubin) can appear. In about $10 \%$ of patients, abnormal heart rhythm can be observed. There have also been cases of squamous cell carcinoma with unknown etiology reported $[45,46]$.
Adverse drug reactions that occur more often during treatment with voriconazole than posaconazole are sinusitis, hypoglycemia, hypokalemia, depression, hallucinations, anxiety, headache and dizziness, peripheral edema, thrombophlebitis, hypotension, acute respiratory distress syndrome, pulmonary edema, jaundice, backache, acute renal failure and hematuria [14-16].

The treatment with posaconazole is often $(\geq 1 / 100$ to $<1 / 10)$ connected with the following ADR: neutropenia, electrolyte dysfunction, anorexia, paresthesia, dizziness, drowsiness, headache, vomiting, nausea, stomachache, diarrhea, dyspepsia, dry mouth, flatulence, elevated ALT, AST, alkaline phosphatase, GGT, lactate dehydrogenase, bilirubin, pyrexia, asthenia, tiredness [24].

The most frequent ADR of voriconazole and posaconazole are presented in Table 4 [16, 24].

\section{Drug interactions}

Voriconazole can increase serum levels of astemizole, terfenadine, cisapride, pimozide and quinidine. This leads to prolongation of the QTC and arrhythmia. The drug is also connected with the increase of sirolimus and ergot alkaloids plasma concentrations. The co-administration of the mentioned drugs with voriconazole is contraindicated. Voriconazole increases the serum levels of cyclosporine A and tacrolimus, so reduction of the dose of these drugs when co-administered is recommended. The drug increases the action of warfarin and other anticoagulants. Monitoring of prothrombin time as well as dose adjustments are needed. Monitoring of blood glucose is recommended during co-administration with sulphonylureas. The administration of voriconazole with statins may lead to rhabdomyolysis, with benzodiazepines can result in prolongation of sedative action, and with vincristine and vinblastine can result in neurotoxicity. The administration of voriconazole with an enzymatic inductor such as phenytoin and rifabutin is not recommended. The need for co-administration

Table 4. Most common adverse drug reactions of voriconazole and posaconazole

\begin{tabular}{|c|c|c|}
\hline Adverse drug reaction & Voriconazole & Posaconazole \\
\hline Stomach ache, nausea, vomiting, diarrhea & + & + \\
\hline Paresthesia, somnolence, dizziness & + & + \\
\hline Electrolyte imbalance & + & + \\
\hline Hypoglycemia & + & - \\
\hline AST, ALT abnormalities & + & + \\
\hline Immune system disorders & + (sinusitis) & - \\
\hline Rash & + & + \\
\hline Pyrexia, asthenia & + & + \\
\hline $\begin{array}{l}\text { Psychological disturbances, depression, hallucination, } \\
\text { anxiety }\end{array}$ & + & - \\
\hline Peripheral edema & + & - \\
\hline Thrombophlebitis & + & - \\
\hline Respiratory distress & + & - \\
\hline Renal failure & + & - \\
\hline Visual impairment & + & - \\
\hline
\end{tabular}


Table 5. Voriconazole and posaconazole drug interactions

\begin{tabular}{|lll}
\hline Antifungal agent & $\begin{array}{l}\text { Drugs and other substances decreasing } \\
\text { antifungal agent serum levels }\end{array}$ & $\begin{array}{l}\text { Drugs and other substances increasing antifungal agent serum } \\
\text { levels }\end{array}$ \\
\hline $\begin{array}{l}\text { Rifampicin, rifabutin, carbamazepine, } \\
\text { phenytoin, delavirdine, efavirenz, } \\
\text { nevirapine, ritonavir, amprenavir, darunavir, } \\
\text { phenobarbital, mephobarbital, hexobarbital, } \\
\text { pentobarbital, secobarbital, butabarbital }\end{array}$ & $\begin{array}{l}\text { Cimetidine, fluconazole, omeprazole, oral contraceptives } \\
\text { Posaconazole }\end{array}$ \\
$\begin{array}{l}\text { Phenytoin, cimetidine, famotidine, } \\
\text { ranitidine, esomeprazole, lansoprazole, } \\
\text { omeprazole, pantoprazole, metoclopramide, } \\
\text { rifabutin, efavirenz, fosamprenavir }\end{array}$ & $\begin{array}{l}\text { Posaconazole, as an enzymatic inhibitor, mainly increases } \\
\text { the plasma concentrations of other drugs such as: quinidine, } \\
\text { pimozide, astemizole, terfenadine, midazolam, amlodipine, } \\
\text { diltiazem, felodipine, nifedipine, nitrendipine, verapamil, } \\
\text { dihydroergotamine, ergotamine, methysergide, cyclosporine A, } \\
\text { sirolimus, tacrolimus, cisapride, atorvastatin, lovastatin, } \\
\text { simvastatin, vinblastine, vincristine, vinorelbine }\end{array}$ \\
\hline
\end{tabular}

Table 6. Comparison of therapeutic recommendations for co-administration of voriconazole and posaconazole with other drugs

Drug

\begin{tabular}{|c|c|c|}
\hline & \multirow[b]{2}{*}{ voriconazole } & \\
\hline & & posaconazole \\
\hline $\begin{array}{l}\text { Astemizole, pimozide, } \\
\text { quinidine, terfenadine }\end{array}$ & Contraindicated & Contraindicated \\
\hline Efavirenz & $\begin{array}{l}\text { Contraindicated in standard doses - need for } \\
\text { modification }\end{array}$ & $\begin{array}{l}\text { Should be avoided unless the benefit outweighs the } \\
\text { risk }\end{array}$ \\
\hline Rifabutin & $\begin{array}{l}\text { Should be avoided unless the benefit outweighs the } \\
\text { risk }\end{array}$ & $\begin{array}{l}\text { Should be avoided unless the benefit outweighs the } \\
\text { risk }\end{array}$ \\
\hline Phenytoin & $\begin{array}{l}\text { Should be avoided unless the benefit outweighs the } \\
\text { risk }\end{array}$ & $\begin{array}{l}\text { Should be avoided unless the benefit outweighs the } \\
\text { risk }\end{array}$ \\
\hline Cimetidine & No contraindications & Avoid combined therapy \\
\hline Omeprazole & Dose adjustment to $20 \mathrm{mg}$ & Avoid combined therapy \\
\hline Statins & Dose adjustment & Contraindicated \\
\hline Vinca alkaloids & Dose adjustment & $\begin{array}{l}\text { Should be avoided unless the benefit outweighs the } \\
\text { risk. }\end{array}$ \\
\hline Sirolimus & Contraindicated & $\begin{array}{l}\text { Should be avoided unless the benefit outweighs the } \\
\text { risk. }\end{array}$ \\
\hline $\begin{array}{l}\text { Cyclosporine A, } \\
\text { tacrolimus }\end{array}$ & $\begin{array}{l}\text { Careful monitoring for any occurrence of drug toxicity } \\
\text { and/or lack of efficacy, and dose adjustment may be } \\
\text { needed }\end{array}$ & $\begin{array}{l}\text { Careful monitoring for any occurrence of drug } \\
\text { toxicity and/or lack of efficacy, and dose adjustment } \\
\text { may be needed }\end{array}$ \\
\hline $\begin{array}{l}\text { HIV protease } \\
\text { inhibitors }\end{array}$ & $\begin{array}{l}\text { Careful monitoring for any occurrence of drug toxicity } \\
\text { and/or lack of efficacy, and dose adjustment may be } \\
\text { needed }\end{array}$ & $\begin{array}{l}\text { Careful monitoring for any occurrence of drug } \\
\text { toxicity and/or lack of efficacy, and dose adjustment } \\
\text { may be needed }\end{array}$ \\
\hline Benzodiazepines & Dose adjustment & Dose adjustment \\
\hline Digoxin & No contraindications & $\begin{array}{l}\text { Careful monitoring for any occurrence of drug } \\
\text { toxicity and/or lack of efficacy, and dose adjustment } \\
\text { may be needed }\end{array}$ \\
\hline Sulphonylureas & Careful monitoring of blood glucose is recommended & $\begin{array}{l}\text { Careful monitoring of blood glucose is } \\
\text { recommended }\end{array}$ \\
\hline
\end{tabular}

makes it necessary to increase the triazole maintenance dose. Monitoring of methadone adverse drug reactions is recommended. Posaconazole co-administered with ergot alkaloids may lead to prolongation of QTc. The drug is one of the CYP3A4 inhibitors, which creates a need for dose adjustment in co-administration with many other drugs $[14,16,24,28]$.

In Table 5 voriconazole and posaconazole drug interactions leading to changes in plasma concentrations of antifungal agents are presented $[16,24,28]$. 
Table 7. Therapeutic drug monitoring of voriconazole and posaconazole

\begin{tabular}{|c|c|c|c|c|}
\hline \multirow[t]{2}{*}{ Antifungal agent } & \multirow{2}{*}{$\begin{array}{l}\text { Indication for serum level } \\
\text { monitoring }\end{array}$} & \multirow{2}{*}{$\begin{array}{l}\text { Time of first serum level } \\
\text { detection (days) }\end{array}$} & \multicolumn{2}{|c|}{ Minimal concentration $(\mu \mathrm{g} / \mathrm{ml})$} \\
\hline & & & Effectiveness & Safety \\
\hline Voriconazole & $\begin{array}{l}\text { Young age, no treatment } \\
\text { response, gastrointestinal } \\
\text { disorders, hepatobiliary } \\
\text { disorders, neurological } \\
\text { disorders, other drugs co- } \\
\text { administration, IV to p.o. } \\
\text { switch, long-term therapy }\end{array}$ & $4-7$ & $\begin{array}{l}\text { Prophylaxis } \\
\quad>0.5 \\
\text { Therapy } \\
>1 \text { to } 2\end{array}$ & $<6$ \\
\hline Posaconazole & $\begin{array}{l}\text { Older age, no response to } \\
\text { the therapy, gastrointestinal } \\
\text { disorders, hepatobiliary } \\
\text { disorders, other drugs, gavage, } \\
\text { GVHD }\end{array}$ & $>7$ & $\begin{array}{l}\text { Prophylaxis } \\
\qquad 0.7 \\
\text { Therapy } \\
>0.7 \text { to } 1.250\end{array}$ & $\begin{array}{l}\text { Has not been } \\
\text { determined }\end{array}$ \\
\hline
\end{tabular}

Table 8. Comparison of clinical pharmacology of voriconazole and posaconazole

\begin{tabular}{|c|c|c|}
\hline Variable & Voriconazole & Posaconazole \\
\hline \multicolumn{3}{|c|}{ Similarities } \\
\hline Drug family & \multicolumn{2}{|c|}{ Triazole antifungal drugs } \\
\hline Method of administration & \multicolumn{2}{|c|}{ p.o., i.v. } \\
\hline Effectiveness in treatment of & \multicolumn{2}{|c|}{ Invasive aspergillosis, fusariosis, candidiasis } \\
\hline Safety & \multicolumn{2}{|c|}{ Narrow therapeutic index (recommendation for TDM) } \\
\hline \multicolumn{3}{|c|}{ Differences } \\
\hline Additional effectiveness against & Scedosporium spp. & Coccidioides, chromoblastomycosis \\
\hline Dosage recommendations & $\begin{array}{l}\text { Two doses per day; in the first } 24 \mathrm{~h} \text { - loading } \\
\text { dose, during next days - maintenance dose }\end{array}$ & $\begin{array}{l}\text { Four doses for p.o. formulations, single dose for i.v. } \\
\text { formulations }\end{array}$ \\
\hline Pharmacokinetics & Non-linear in adults, linear in children & Linear \\
\hline Bioavailability & $>95 \%$ & Depending on the dosage regimen and food intake \\
\hline Absorption & Decreased by high fat meals intake & Increased by high fat meals intake \\
\hline Protein binding (\%) & 58 & $>98$ \\
\hline $\begin{array}{l}\text { Distribution ratio } \\
(1 / \mathrm{kg})\end{array}$ & 4.6 & $7-25$ \\
\hline Steady state after (days) & $5-6$ & $7-10$ \\
\hline Maximal time (h) & $1-2$ & $3-6$ \\
\hline Metabolism & isoenzymes & P-glycoprotein, UDP-glucuronyltransferase \\
\hline Mainly through & phase I reaction & phase $\|$ reaction \\
\hline Half-life (h) & $6-12$ & $15-35$ \\
\hline Elimination & $\begin{array}{l}\text { hepatic, }<2 \% \text { unchanged } \\
\text { eliminated with urine }\end{array}$ & $\begin{array}{c}66 \% \text { of unchanged drug eliminated with feces, } \\
<1 \% \text { eliminated with urine }\end{array}$ \\
\hline
\end{tabular}

The main drug interactions and recommendations for co-administration of voriconazole and posaconazole with other drugs are demonstrated in Table $6[16,24]$.

\section{Therapeutic drug monitoring of voriconazole and posaconazole}

According to the pharmacokinetics of voriconazole and posaconazole, adverse drug reactions and other factors influencing the serum levels, therapeutic drug monitoring (TDM) is required for optimization of treatment of invasive fungal infections, but there is only a limited amount of research on the topic. Brüggemann et al. state in their article the urgent need for TDM enrollment, and point out the areas with lack of information [47]. The study carried out by Soler-Palacín et al. suggested the need for inclusion of therapeutic drug monitoring in the routine procedures among the pediatric population [48]. In the case of 
posaconazole treatment, TDM is needed only in high-risk patients, to determine compliance [49-51]. The British Society for Medical Mycology laid down guidelines for TDM of antifungal agents. According to the publication, "therapeutic drug monitoring should be performed in the majority of patients receiving voriconazole or posaconazole" [52].

In Table 7, the most important information connected to TDM of antifungal agents is presented [28, 44].

In conclusion, among numerous similarities, the clinical pharmacology of voriconazole and posaconazole exhibits some differences as well, as demonstrated in this article. It is necessary to take them into consideration in everyday clinical praxis. Table 8 is a summary of all similarities and differences between the two drugs discussed in this article $[16,20,24,35]$.

\section{The authors declare no conflict of interest.}

\section{References}

1. Arendrup MC, Sulim S, Holm A, Nielsen L, et al. Diagnostic issues, clinical characteristics, and outcomes for patients with fungemia. J Clin Microbiol 2011; 49: 3300-8.

2. Butrym A, Zywar K, Dzietczenia J, Mazur G. Inwazyjne zakażenia grzybicze u pacjentów z nowotworami hematologicznymi. Mikol Lek 2011; 18: 47-53.

3. Czyż A, Dębska-Szmich S. Powikłania infekcyjne. In: Onkologia kliniczna. Krzakowski M, Potemski P, Warzocha K,Wysocki P (eds.). Via Medica, Gdańsk 2014, 177-96.

4. Girmenia C. New generation azole antifungals in clinical investigation. Expert Opin Investig Drugs 2009; 18: 1279-95.

5. Kaliszewski J, Krawczuk-Rybak M, Leszczyńska E, Łuczyński W, Muszyńska-Rosłan K, Solarz E. Następstwa leczenia choroby nowotworowej. In: Kompendium onkologii dziecięcej. Krawczuk-Rybak M (ed.), Białystok 2004; 74-9.

6. Kazanowska B, Reich A, Chybicka A. Aspergiloza zatok sitowych i oczodołu u dziecka z ostrą białaczką limfoblastyczną - kombinowane leczenie kaspofunginą i worikonazolem. Mikol Lek 2005; 12: 297-9.

7. Krzemieniecki K. Leczenie wspomagające w onkologii. Termedia, Poznań 2008.

8. Sieniawski M, Bohlius J, Cornely OA. Znaczenie profilaktyki pierwotnej zakażeń grzybiczych u pacjentów ze schorzeniami hematologicznymi. Nowotwory 2004; 54: 281-9.

9. Aguilar G, Delgado C, Corrales I, et al. Epidemiology of invasive candidiasis in a surgical intensive care unit: an observational study. BMC Res Notes 2015; 8: 491.

10. Stempel JM, Hammond SP, Sutton DA, Weiser LM, Marty FM. Invasive Fusariosis in the Voriconazole Era: Single-Center 13-Year Experience. Open Forum Infect Dis 2015; 2: ofv099.

11. Heng SC, Slavin MA, Chen SC a, Heath CH, Nguyen Q, Billah B, Nation RL, Kong DC. Hospital costs, length of stay and mortality attributable to invasive scedosporiosis in haematology patients. J Antimicrob Chemother 2012; 67: 2274-82.

12. Arvanitis M, Anagnostou T, Fuchs BB, Caliendo AM, Mylonakis E. Molecular and nonmolecular diagnostic methods for invasive fungal infections. Clin Microbiol Rev 2014; 27: 490-526.

13. Lewis RE. Current concepts in antifungal pharmacology. Mayo Clin Proc 2011; 86: 805-17.

14. Passowicz-Muszyńska E, Jankowska R, Weryńska B. Nowe leki przeciwgrzybicze stosowane $\mathrm{w}$ terapii grzybic głębokich. Mikol Lek 2007; 14: 137-41.

15. Adamski Z. Nowości i przyszłość w terapii przeciwgrzybiczej. Mikol Lek 2005; 12: 115-21.

16. Aneks i charakterystyka produktu leczniczego VFEND, data zatwierdzenia: 21.02.2012.
17. Grudzień M, Pałka K, Pluciński F, Mazurek A. Molecular proprerties impact on bioavailability of second generation triazoles antifungal agents. Acta Pol Pharm 2013; 70: 869-72.

18. Morris A. Review: Voriconazole for prevention or treatment of invasive fungal infections in cancer with neutropenia. ACP J Club 2014; 161: 8.

19. Szymankiewicz M, Dancewicz M. Aktywność in vitro worikonazolu i kaspofunginy wobec szczepow Candida spp. oceniana metodą E-testu. Mikol Lek 2008; 15: 13-5.

20. Sandherr M, Maschmeyer G. Pharmacology and metabolism of voriconazole and Posaconazole in the treatment of invasive aspergillosis: review of the literature. Eur J Med Res 2011; 16: 139-44.

21. Al Abdely HM, Alkhunaizi AM, Al Tawfiq JA, Hassounah M, Rinaldi MG, Sutton DA. Successful therapy of cerebral phaeohyphomycosis due to Ramichloridium mackenziei with the new triazole posaconazole. Med Mycol 2005; 43: 91-5.

22. Herbrecht R, Kessler R, Kravanja C, Meyer MH, Waller J, Letscher-Bru V. Successful treatment of Fusarium proliferatum pneumonia with posaconazole in a lung transplant recipient. J Hear Lung Transpl 2004; 12: 1451-4.

23. Imbernón A, Agud JL, Cuétara MS, et al. Successful therapy of progressive rhino-orbital mucormycosis caused by Rhizopus arrhizus with combined and sequential antifungal therapy, surgery and hyperbaric therapy. Med Mycol Case Rep 2014; 6: 51-4.

24. Aneks i charakterystyka produktu leczniczego Noxafil, datazatwierdzenia 21.10.2005.

25. Yenisehirli G, Bulut N, Yenisehirli A, Bulut Y. In Vitro Susceptibilities of Candida albicans Isolates to Antifungal Agents in Tokat, Turkey. Jundishapur J Microbiol 2015; 8: e2805

26. Pelaez T, Monteiro MC, Garcia-Rubio R, Bouza E, Gomez-Lopez A, Mellado E. First detection of Aspergillus fumigatus azole-resistant strain due to Cyp51A TR46/Y121F/T289A in an azole-naive patient in Spain. New Microbes New Infect 2015; 6: 33-4.

27. Romanowska E. Mechanizmy oporności na leki przeciwgrzybicze. In: Zakażenia Szpitalne. Dzierżanowska D (ed.). $\alpha$-medica press, Bielsko-Biała 2008; 497-507.

28. Andes D, Pascua A, Marchetti O. Antifungal therapeutic drug monitoring: Established and emerging indications. Antimicrob Agents Chemother 2009; 53: 24-34.

29. Amsden JR, Gubbins PO, McConnell S, Anaissie E. Steady-state pharmacokinetics of oral voriconazole and its primary metabolite, N-oxide voriconazole, pre- and post-autologous peripheral stem cell transplantation. Antimicrob Agents Chemother 2013; 57: 3420-3.

30. Dolton MJ, Mikus G, Weiss J, Ray JE, McLachlan AJ. Understanding variability with voriconazole using a population pharmacokinetic approach: Implications for optimal dosing. I Antimicrob Chemother 2014; 69: 1633-41.

31. Geist MJ, Egerer G, Burhenne J, Mikus G. Safety of voriconazole in a patient with CYP2C9*2/CYP2C9*2 genotype. Antimicrob Agents Chemother 2006; 50: 3227-8.

32. Scott S, Sangkuhl K, Shuldiner A, Hulotb J, Thorn C, Altman R, et al. PharmGKB summary: very important pharmacogene information for cytochrome P450, family 2, subfamily C, polypeptide 19. Pharmacogenet Genomics 2012; 22: 159-65.

33. Moriyama B, Jarosinski PF, Figg WD, Henning SA, Danner RL, Penzak SR, et al. Pharmacokinetics of intravenous voriconazole in obese patients: Implications of CYP2C19 homozygous poor metabolizer genotype. Pharmacotherapy 2013; 33: 19-22.

34. Moriyama B, Falade O, Leung J, Penzak SR, Jjingo C, Huang X, et al. Prolonged Half-life of voriconazole in CYP2C19 Homozygous poor Metabolizer recieving vincristine chemotherapy: avoiding a Serious Adverse Drug Interaction. Mycoses 2011; 54: 1-5.

35. Hope WW. Population pharmacokinetics of voriconazole in adults. Antimicrob Agents Chemother 2012; 56: 526-31.

36. Karlsson MO, Lutsar I, Milligan PA. Population pharmacokinetic analysis of voriconazole plasma concentration data from pediatric studies. Antimicrob Agents Chemother 2009; 53: 935-44.

37. Neely M, Rushing T, Kovacs A, Jelliffe R, Hoffman J. Voriconazole Pharmacokinetics and Pharmacodynamics in Children. Clin Infect Dis 2010; 50: 27-36. 
38. Kuo IF, Ensom MHH. Role of Therapeutic Drug Monitoring of Voriconazole in the Treatment of Invasive Fungal Infections. Can J Hosp Pharm 2009; 62: 469-82.

39. Dolton MJ, Brüggemann RJM, Burger DM, McLachlan AJ. Understanding variability in posaconazole exposure using an integrated population pharmacokinetic analysis. Antimicrob Agents Chemother 2014; 58: 6879-85.

40. Nagappan V, Deresinski S. Reviews of anti-infective agents: posaconazole: a broad-spectrum triazole antifungal agent. Clin Infect Dis 2007; 45: 1610-7.

41. Sansone-Parsons A, Krishna G, Simon J, et al. Effects of age, gender, and race/ethnicity on the pharmacokinetics of posaconazole in healthy volunteers. Antimicrob Agents Chemother 2007; 51: 495-502.

42. Kersemaekers WM, van lersel T, Nassander U, et al. Pharmacokinetics and Safety Study of Posaconazole Intravenous Solution Administered Peripherally to Healthy Subjects. Antimicrob Agents Chemother 2015; 59: 1246-51.

43. Jeziorna M, Klimowicz A, Bielecka-Grzela S. Wpływ glikoproteiny P oraz wybranych izoenzymów cytochromu P-450 na azolowe leki przeciwgrzybicze. Post Dermatol Alergol 2009; 26: 533-8.

44. Dolton MJ, Ray JE, Marriott D, McLachlan AJ. Posaconazole exposure-response relationship: Evaluating the utility of therapeutic drug monitoring. Antimicrob Agents Chemother 2012; 56: 2806-13.

45. Wojenski D, Bartoo G, Merten J, et al. Voriconazole exposure and the risk of cutaneous squamous cell carcinoma in allogeneic hematopoietic stem cell transplant patients. Transpl Infect Dis 2015; 17: 250-8.

46. Epaulard O, Villier C, Ravaud P, Chosidow O, Blanche S. MAJOR ARTICLE A Multistep Voriconazole-Related Phototoxic Pathway May Lead to Skin Carcinoma : Results From a French Nationwide Study. Clin Infect Dis 2013; 57: 182-8.

47. Aarnoutse RE. Fundament and prerequisites for the application of an antifungal TDM service. Curr Fungal Infect Rep 2015; 9: 122-9.

48. Soler-Palacín P, Frick MA, Martín-Nalda A, et al. Voriconazole drug monitoring in the management of invasive fungal infection in immunocompromised children: A prospective study. J Antimicrob Chemother 2012; 67: 700-6.

49. Goodwin MI, Drew RH. Antifungal serum concentration monitoring: An update. J Antimicrob Chemother 2008; 61: 17-25.

50. Gross BN, Ihorst G, Jung M, Wäsch R, Engelhardt M. Posaconazole therapeutic drug monitoring in the real-life setting: A single-center experience and review of the literature. Pharmacotherapy 2013; 33: 1117-25.

51. Hussaini T, Rüping M., Farowski F, Vehreschild J., Cornely O. Therapeutic drug monitoring of voriconazole and posaconazole. Pharmacotherapy 2011; 31: 214-25.

52. Ashbee HR, Barnes RA, Johnson EM, Richardson MD, Gorton R, Hope WW. Therapeutic drug monitoring (TDM) of antifungal agents: guidelines from the British Society for Medical Mycology. J Antimicrob Chemother 2014; 69: 1162-76.

\section{Address for correspondence}

\section{Beata Sienkiewicz}

Chair and Department of Clinical Pharmacology

Wroclaw Medical University

Borowska $211 \mathrm{~A}$

50-556 Wroclaw, Poland

Submitted: 24.08 .2015

Accepted: $\quad 30.11 .2015$ 